
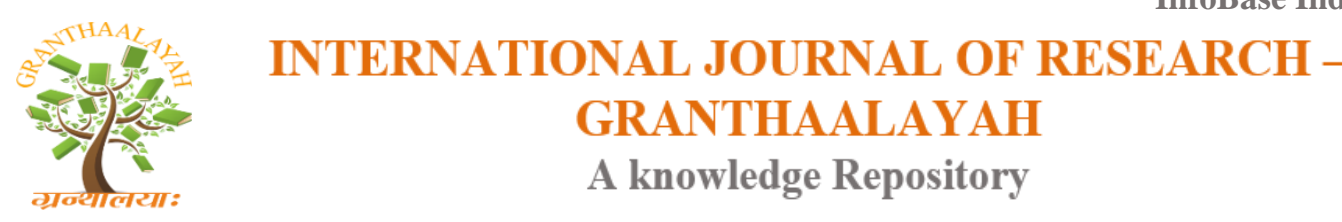

Management

\title{
MANAGEMENT OF COMMUNITY SERVICE OF ISLAMIC UNIVERSITIES AT BANTEN
}

\author{
Agus Gunawan *1 \\ ${ }^{* 1}$ Department of Islamic Education Management, Post Graduate Program, State Islamic Institute \\ of Sultan Maulana Hasanuddin Banten, Indonesia
}

DOI: https://doi.org/10.29121/granthaalayah.v5.i4.2017.1829

\begin{abstract}
This study used a qualitative naturalistic approach. Purposive sampling technique used by researchers as an instrument. Techniques of collecting data through interview, observation and documentation. Steps to be taken in data processing is: (1) test the validity of data is carried out through the triangulation of data, member check, and audit trail; (2) The data analysis was done in a sustainable and developed throughout the program; (3) Data Reduction; (4) Data presentation; and (5) Make a conclusion. Forms of community service activities developed and conducted by the University of Muhammadiyah Tangerang include: Field Work Experience, Founding Village, Campus of Environment, Partnership Cooperation, Training and Publishing journals. While the form of community service activities developed and conducted by the University Mathla'ul Anwar Pandeglang includes: paper publication activities, upgrading activities, assistance to non-formal education, assistance to the efforts of eradicate illiteracy, sending teams sports and art, the delivery of missionary endeavor, community development, coaching the boarding school students, also assistance to businesses that do not make a profit.
\end{abstract}

Keywords: Management; Community Service; Islamic College; Banten.

Cite This Article: Agus Gunawan. (2017). "MANAGEMENT OF COMMUNITY SERVICE OF ISLAMIC UNIVERSITIES AT BANTEN.” International Journal of Research - Granthaalayah, 5(4), 352-368. https://doi.org/10.29121/granthaalayah.v5.i4.2017.1829.

\section{Introduction}

Placed education as the main capital to construct and save the nation is the right thing. Human life grows along with the progress of science and technology, the rapid flow of telecommunication and globalization, so that the human desire grows too, which sometimes it is unlimited. Human life are increasingly complex will bring socio-cultural changes and the resulting affect to social systems, values attitudes and behavior patterns of individuals and communities. This life will always grow and change, people need the tools of adjustment to deal the change; The human need is increasingly rising, people need a balance to solve it; The human 
need not only material, but mental and spiritual as well, so people need learning process through education. Education helps human on process of quality maturation, understand the meaning and nature of life. According to Dedi Mulyasana ${ }^{1}$, educational role to help people understand the meaning behind the change and help people understand the meaning contained in the new values and able to adjust on something new.

National education aims to educate the nation and developed Indonesian completely, a faithful and piety towards God Almighty and have good character, knowledge and skills, physical and spiritual health, stable personality, independent and responsibilities of community and nationality. As stated in the Law National Education System ${ }^{2}$, that: The national education serves to develop the ability and character development and civilization of the nation in the context of educate the nation, aims to develop students' skill to be a faithful and piety to God Almighty, have good personality, healthy, knowledgeable, skilled, independent, and become democratic and responsible citizens.

The existence of education in college has a strategic role in the life of the nation which is implemented through Tridharma universities, namely education, research and community service. In general, these roles are the development of science and technology and at the same time contribute to develop faith and piety. The function of universities is to provide education to produce a well-educated human, in accordance with the purpose of higher education.

Law of the Republic of Indonesia Number 20 of 2003 on National Education System Article 20, paragraph 2, explain that colleges are obliged to provide education, research, and community service. Therefore, the college has the task of improving the educational process as optimal as possible to produce qualified students with competitiveness and competence, realizing its existence as scientific institutions academic with producing some innovative finding of public interest and success the development, and improving the ability of the target audience in solving the problem so they able to build themselves. As for the implementation of education, research, and community service should be viewed as a unity of implement the Tridharma University.

The college serves as a center of education, technology, and the transfer of knowledge from lecturers to students as well as high-valued function as agents of change towards community development and nation. Ideally, college imaged as an academic institution or professional education, and as a scientific institution, and institutions dedication to the community and to the nation. This ideal imaging are apparent in the concept of "three responsibilities of Higher Education" (Tridharma University), which confirmed the three functions of universities, namely: education and teaching, research, and community service. This ideal image is also imposed on character of tutors and graduates. All components of the academic, the lecturers and students have an obligation to implement the three responsibilities of Higher Education: education, research and community service.

The university management is very important to promote and enhance competitiveness in the global market, improving the health of the organization, improve the effectiveness and efficiency of the entire assets and resources, and to improve the quality of governance and public image. The main strength of Islamic Higher Education is based on the existence of Islamic Universities that mainly have been recognized by the community, the academic community which has a 
strong commitment to developing Islamic values; And the weak of role of Islamic Higher Education (PTI), particularly in the field of community service, it is because PTI: First, it is not make maximal devotion network central role in community development; second, PTI's role in community development is ad hoc; Third, the awareness of the PTI is not optimal in developing community ${ }^{3}$. Another condition, the Islamic university is very varied in its implementation and lack of control; so the Ministry of Religious Affairs of the Republic of Indonesia through the Director General of Islamic Education directs the development of the private PTAI for the next five years to control and development, quality improvement and quality of academic services, as well as the implementation of the National Standard of Higher Education ${ }^{4}$.

In Banten there are some universities which have Private Islamic University basic which are building and improving quality with a variety of activities, both the activities of students and lecturers. Results of preliminary research studies, there are two universities based Islamic Religion of the most popular in the province of Banten, these are Muhammadiyah University of Tangerang (UMT) and the Mathla'ul Anwar University (UNMA) Pandeglang. In both the college, community service activities are still left behind, compared with academic education activities, viewed from the involvement of lecturers and the amount of funds available in the budget, giving the impression of dedication to the community institutions only as a complementary structure in PTI. Nevertheless, community service activities is still running. Even community service performed individually and institutionally.

Reality above are supported by Syahrijal Abbas, that universities at Aceh conducts educational and teaching activities $80 \%$, while the research activities and community service is only $20 \%$. Those that run the education and teaching of $90 \%$ as well as research activities and community service, only $10 \%^{5}$. This means that many colleges lack of attention to research and community service. Meanwhile, according to the provisions of universities in actualize the functions and roles of carry out the academic education, do the research and develop also disseminate knowledge to improve the level of human life in enriching the national culture. Therefore, the implementation of education, researches and community services so balanced and integrated.

Form of the activities of community service agency adapted to the vision and mission of the college which is translated by the community service agencies. In other words, the formulation of the vision and mission of the college is implementing Community Service Organization (LPM), and LPM should be able to demonstrate the distinctiveness of the institution in accordance with the potential of the resource also a passion or commitment of all the elements involved in the academic of that universities.

\section{Methodology}

This study used a qualitative naturalistic approach. Purposive sampling technique used by researchers as an instrument. Techniques of collecting data through interview, observation, and documentation. Steps in data processing are: (1) tested the validity of data was carried out through the triangulation of data, membercheck, and audit trail; (2) The data analysis was done in a sustainable and developed throughout the program; (3) Reduction of data; (4) Presentation of data; and (5) Make conclusions or verifications ${ }^{6}$. 
The process of data analysis began since the researcher take into the background by examining data collected through interview, observation, and documentation. Then the data is reduced by making abstractions in summary form of the existing data, and then organized into units. The units are categorized while giving the code, and then proceed with the analysis of data validity checking. The next stage is reporting the whole process from beginning to end of the study. From the preliminary studies, preparation of data processing design and writing the final report.

Sources of qualitative data is done in Private Islamic University, the Mathla'ul Anwar University (UNMA) in Menes Pandeglang and Muhammadiyah University of Tangerang (UMT). These Two Higher Education is an Islamic college domiciled in Banten Province.

Data supporting such as information, documents, records of events, facts, opinions and concepts and written policies and unwritten from campus leaders and faculty. The primary data source or the subject of the study include the academic community that is representative of the Islamic university lecturer, leader of LPM, and leader of study program, also supporting data sources of student elements, elements of the society, and stakeholders.

The purpose of this study are: (1) Uncover the service management to community (LPM), ranging from planning, implementation, and evaluation of the implementation, and the dominant aspects that encourage lecturers and students of Islamic Universities in carrying out community service; (2) Determine the value addition of the activities of lecturers and students in community service activities; (3) uncover the special things, unique and specific, also the unspoken with small subjects.

\section{Findings}

\subsection{Process of Planning, Implementation and Evaluation of Community Services of Islamic Universities at Banten}

\subsubsection{Planning of Community Service Program to society of UMT}

Dedication to the community by the college is defined as the practice of science, technology / art (science and technology) and conducted by the college institutionalized through scientific methods directly to the society who need it in successing the development and build human development. The institute is headed by a chairman, assisted by a vice and sektretaris. Mainly, LP3M is managing all the activities of research, development and community service that performed by lecturers and students at the University of Muhammadiyah Tangerang.

The role of the planning community service program in accordance with its mission, LPM of UMT is to coordinate and carry out the functions of institutional managers in developing programs / community service activities conducted by the academic community of UMT from faculties, departments, and programs of study. In addition, LPM of UMT implements and develops cooperation with other universities, departments / government agencies, private organizations, and other social organizations. Everything was done to develop an atmosphere that fosters sensitivity and a willingness to implement community service activities through the application of science and technology, action research, the development of the research and 
development of regions with the principle of science and scientific charity and the fundamental principles of education and culture with a scientific approach, disciplinary cross, and crosssector. In designing and developing programs, LPM of UMT uses guidelines that applied.

\subsubsection{Planning Program Community Service to society of Math'laul Anwar University (UNMA)}

Planning program community service in Mathla'ul Anwar implemented lean on Allah Subhanahu Wata'alla and responsibility to society so that operational of higher education of Mathla'ul Anwar in carrying out its activities determined by the runway at:

- Pancasila and the Constitution of 1945

- Law on National Education System No. 20 of 2003

- Government Regulation No. 60 of 1999

- AD / ART Executive Board of Mathla'ul Anwar

- University STATUTE of Mathla'ul Anwar

- University's Strategic Plan of Mathla'ul Anwar

- Other provisions relating to the provision of higher education tinggi ${ }^{8}$.

In the preparation of work plans, opinions and suggestions from the target communities desperately need to be considered. Again, it should be endeavored that people assume that the activity is theirs, their efforts to overcome the problems they face with the assistance of representatives from the college, and perhaps also of other elements, for example, of the various relevant agencies. On the contrary, it should be avoided to make they think that the activities is aimed to the colleges and universities, so that they only help. In this work plan should be arranged as possible in order duties, obligations and responsibilities of the respective parties. The growth of a sense of responsibility on the part of the target communities is critical for the successful operation in the future.

\subsection{Implementation of the Community Service Program in Private Islamic College}

\subsubsection{Implementation Program of Community Service at society of UMT}

Community service institutions are operationally responsible on making the procedures for implementing the community service activities and academic staffs are required to follow established procedures. Overall LP3M through every faculty Academic Unit is the central coordinator, mediation and facilities for academic staff.

Lecturer roles as the holder of implementation of activities in the field who take strategic positions against among group and target group (community). The role of lecturers preferred to strengthen local capacity in the planning and implementation of service activities. The strategic roles of lecturers more consultative, organize stakeholders and local capacities, and collaborate among powers mediating relations between community groups with service users and service providers. Lecturer in this context was not placed as actors in the field, but to strengthen local capacity so that the structural component of society is able to develop as a major organ in the changing society in the target area. To strengthen the practical performance on the field, lecturer 
or groups of lecturers are encouraged to involve students who will go directly to the beneficiaries, such as the lower class of society. ${ }^{9}$

\subsubsection{Implementation Program of Community Service at society of UNMA}

University of Mathla'ul Anwar (UNMA) have a common responsibility in developing the three responsibilities of Higher Education. UNMA to always run the three responsibilities of Higher Education. In order to have a clear goal in creating a situation that qualified and dedicated. The development of science and improvement of the learning process not only in the context of the pursuit of ratings, but how far scientists of UNMA were able to contribute to society and the environment.

In this regard, all the elements in the organization at the University of Mathla'ul Anwar must uphold noble values embodied in the organization, which is a high awareness of the importance of quality, each person is responsible for the quality, repairs must be carried out continuously, attentive work ethic, working within the smart work system, work efficiently and effectively, high discipline, do not look for scapegoats for the mistakes and harmonious working climate. It is expected the University of Mathla'ul Anwar as an educational institution can spawn development ideas for development in the field of infrastructure and develop human resource ${ }^{10}$.

\subsection{Evaluation of Community Service Program at Private Islamic College (PTIS)}

\subsubsection{Evaluation of Community Service Program to society of Muhammadiyah University Tangerang}

Policy of community service program at the University of Muhammadiyah particularly University of Muhammadiyah Tangerang (UMT) is done by empower and do practicum on community service. Format of empowerment activities are part of the institution's work program for Research and Community Services LP3M in each financial year until 2013. The format of empowerment activities include empowerment of religious institutions such as the empowerment of madrasah, mosques empowerment, empowerment of schools; socio-economic empowerment program of the society. These fourth empowerment programs in implementation is coordinated by LP3M cooperate with other units on campus. ${ }^{11}$.

Evaluation is closely related to all systems and processes. Relation between the evaluations and planning is planning is arrange based on the results of the assessment or analysis on problem needs, the resources available at least. Relation between evaluation and organization is whether the organization especially UMT as Muhammadiyah University has aligned with the purpose of implementation of Muhammadiyah 'caturdharma' on higher education in the field of education, research, community service also Al-Islam in all muhammadiyah in order to achieve higher educational goals of muhammadiyah ${ }^{12}$.

Evaluation of community service at UMT conducted from early planning to implementation by Internal Auditor Team with the standard guidelines for community service, and results are reported in the form of writing activities. Report delivered to some concern people, according to 'tupoksi' ${ }^{13}$. 


\subsubsection{Evaluation of Community Service Program to community of Mathla'ul Anwar University}

Evaluation of community service programs at each stage should be evaluated, which raised the belief that everything that has been decided is correct, and can step to the next stage safely. But it does not eliminate the possibility of holding refinement during the activity. One of the important things is the evaluation of the results or the impact of all community service activities to target communities.

The evaluation results are not only important as a complete administrative, but also very important to be known by everyone involved, including the targeted communities. Evaluation process of UNMA included elements of stakeholders or target audiences, students and other academic society. So that they know what the outcome during of these activities, also learn how to recognize and measure the changes that occur. In addition to the evaluation carried out during the process, also do in the leadership meeting and also on work meeting at UNMA specifically ${ }^{14}$.

\subsection{Forms of Community Service Has Added Value to the development of Social Change at Private Islamic College}

\subsubsection{Form of Community Service to the society of UMT.}

Cognitive repertoire of the university academicians undoubtedly keep the memory of a missionary concept to them in the three responsibilities of Higher Education which consists of education, research and community service and for the College of Muhammadiyah added to Islamization and all Muhammadiyah. The action research is a form of integrated activities between researchers and community service that designed and implemented collaboratively with other components of society directed towards solving real problems in society.

This activity begins with the identification of the problem, development of alternative model on problem-solving, implementation models, observation, and continuous improvement models (sustainability) in society ${ }^{15}$.

Basically the forms of community service activities that can be developed and carried out by Islamic college including UMT are:

1) Real Work Lecture

2) Village Patronage (development partners)

3) Campus Environment (a model of community service to society around campus)

4) Cooperation Partnership

5) Training, and

6) Publishing jurnal ${ }^{16}$.

\subsubsection{Forms of Community Services of Mathla'ul Anwar University}

LP3M UNMA has two divisions including the Division of Research and Development Division and Serving the Community. Institutionally, LP3M UNMA of Banten responsible for managing academic university community as a whole in community development activities around 
universities as an effort to develop the ability of people, so it can accelerate the achievement of national development goals, and improve the implementation of the missions and functions of universities $^{17}$.

The scope of division program of community service are: 1) The activities of publication paper, 2) Activity upgrading, 3) Assistance to school education, 4) Assistance to the efforts to eradicate illiteracy, 5) Deliver sports team, arts, 6) Deliver man power of da'wah, 7) Environmental Development, 8) Founding boarding school of Students at Mathalul Anwar University, and 9) assistance to nonprofit businesses ${ }^{18}$.

The budget for the realization the programs above are about $\mathrm{Rp} 177,218,000.00$ (one hundred and seventy-seven million two hundred eighteen thousand rupiahs). Each financing of form of the program is determined based on the objectives to be achieved by the program, and there are five forms of program community service, these are (1) Education in Society, (2) Service to the Community, (3) Development of Regional Integrated, and (4) Field Work Experience or KKN ${ }^{19}$.

\subsection{The shapes and steps of Community Service that has additional value to the addition of social change in Private Islamic Universities}

\subsubsection{Steps of Community Service that has additional value to the addition of social change of Muhammadiyah University of Tangerang (UMT)}

A crucial step on develop dedication to the community is the result of the corrective action program evaluation and prevention against possible reoccurrence of the same error. Therefore, the management of community service establishes corrective and preventive action procedure. Corrective actions taken to eliminate the causes of nonconformities to prevent the reoccurrence of the same incident, whereas preventive action taken to eliminate the causes of potential nonconformities in order to prevent non-conformity. Therefore, not only the textbook devotion that must be owned by UMT, but also there must be a standard book of the Community service to society of Muhammadiyah University of Tangerang ${ }^{20}$.

Information source from audits result, quality records, reports, user complaints or other services used as inputs for preventive action. The results of corrective and preventive actions are possible to change or improve procedures or documents existing quality. So that the service user complaints and the nonconformity of the quality system handled according to procedures to be followed up and coordinated with the relevant part. Complaints of service users is recorded and documented, it can be used as a management review meeting agenda. This means that all problems should be followed up ${ }^{21}$.

Community service activities at UMT in the following way: First, the team developed the concept of community service in each department or program; Second, give special allocation to each department or program according to portions or the number of lecturers which is the lecturers are interested in doing community service on behalf of an institution; Third, each lecturer was assigned to the task of teaching in the classroom lectures; Fourth, involving students in accordance with the capacity of UMT students, especially students of the Faculty of Religion, 
because students of Religion faculty mostly are employees, in order the networking with other organizations can developed $^{22}$.

\subsubsection{Steps on Improvement of Community Service at Mathla'ul Anwar University}

Management of colleges needs to provide a legal protection of the existence of an organization of community service, both position of the leader or employees, thus providing a comfort in its management. So the budget of community service in DIPA devoted and improved. And Lecturer give clearer awarded ${ }^{23}$.

Improvement of community service program needs to be clarity in a way: First, every faculty give certain budget; Secondly, the planned objectives program; Third, need encouragement from the leadership so that lecturers who carry out community service by training and equipping the dedication methodology to the community; Fourth, manager of LP3M that is supported by all components of the college to increase networking or collaboration with third parties; and Fifth, the concept of community service in a handbook made and distributed to academicians ${ }^{24}$.

\section{Discussions}

\subsection{Analysis Planning Process of Community Service Program}

In the process of planning a community service program can be started by analyzing the vision and mission of the university that used as the basic of program development, it can be concluded from the above explanation, the establishment background of Muhammadiyah University of Tangerang (UMT) and the Mathla'ul Anwar University (UNMA) constituted a non-governmental organization that empower people concerned in the fields of education, so that the programs run by the organization many years of experience and theories were found based on scientific findings.

Vision, mission and philosophy of both universities has led to a concentration in improving the quality life of society, thus indirectly community empowerment program has been planned in accordance with the concept of strategic management. The vision and mission of an institution is a priority set in advance to determine the strategic planning of an organization in the future, so that based on this model, vision, mission and philosophy both two universities are according with the above models in planning programs devotion of university which caring society.

Vision, mission and social philosophy at both universities strongly support the spirit of empowering the community through educational institutions, and then we can also analyze the implementation stage in the planning of development programs of both universities as below:

The stages above are arranged more detail in the Guidelines of Research Institution, Development and Community Service (LP3M) UMT on a proposal of dedication and reporting of community service. 
This planning process according with the theory of George R. Terry ${ }^{25}$ in his book Principles of Management which classifies management functions into four parts: (1) Planning, (2) Organizing, (3) Actuating, (4) Controlling.

Besides, Nana Mintarti ${ }^{26}$ declares an empowerment program has five phases beginning with identification and ends with evaluation and audit. Vision, mission and program planning work patterns of both universities have made the five stages of planning, so that the output of the community empowerment program initiated by the two universities to a maximum.

Planning theory above usually varies depending on the kind of planning, objectives planning and the context of planning. The general pattern of social planning that mentioned above boosted by Suharto's opinion ${ }^{27}$ that declare the outline planning program was formulated into five stages, there are: (a) Identification of the problems; (B) Determination of goals; (C) Preparation and development program plans; (D) Implementation of the program; and (e) Evaluation of program.

Planning empowerment program has been systematically on designing empowerment programs based on community needs. Planning empowerment program will be successful if it is supported by the right college organization structure at both universities.

\subsection{Analysis Implementation Process Community Service Program}

In the implementation of community service programs at UMT involve all parties in the campus from the Rector to students, such as KKN-PPM program, community service programs performed by students of UMT is guided by lecturers from various faculties, so the result would be maximum. KKN-PPM activities undertaken by UMT are a thematic KKN-PPM with POSDAYA form (Family Empowerment Post) spread over at the target area of UMT. Posdaya in the initiation concept by foundation independent funds was formed, nurtured and developed as a community institution in the form of forums gathering, advocacy, communication, education and container of activities to strengthening the functions of an integrated family that established and implemented from, by and for families and communities. KKN Posdaya is one type of thematic aims to create, foster and develop Posdaya as a new innovation in empowering the community, through the utilization of local human and natural resources. KKN concept is implemented by UMT in four districts there are district Teluk Naga, District Pakuhaji, District Sepatan and District East Sepatan. While Team Composition according to arable program which covers four areas, namely education, health, entrepreneurship and the environment, the members sought to have the relevant background knowledge and fostered by the supervisor field (DPL).

KKN-PPM program in form of Posdaya has just implemented by UMT in 2013, as many as 813 students to participate in this KKN Posdaya fostered by 40 DPL of all faculty at UMT.

Community service program was conducted by Mathla'ul Anwar University (UNMA) Pandeglang, the university has conducted a community service program with several models:

1) Activities of publication article

2) The training and coaching is good for UKM, educators and the general public

3) Help to eradicate illiteracy

4) Aid to non-formal education or PKBM 
5) Deliver sports teams and arts

6) Deliver man power of 'dakwah'

7) Assistance to nonprofit business

8) Lecture at real work

9) The socio-religious activities

10) Research

These activities are carried out during UNMA established from 2000 and was coordinated by the Institute for Research and Community Service (LP3M) of UNMA, until the 2011 which recorded as many as 3705 students are actively involved in community service programs forming their community work around Lebak, Pandeglang, District Serang and Tangerang regency. UNMA community service programs commonly performed except $\mathrm{KKN}$ and research is eliminate illiteracy, mentoring community learning centers (PKBM), the economic development of UKM, youth skills training, and applied research.

In 2013, UNMA already was working with Foundation of independent funds to adapt the program thematic of KKN-PPM Posdaya. Posdaya adapted by UNMA is based Posdaya Mosque. The goals of KKN Posdaya mosque-based in Pandeglang, namely (1) empowering community groups (especially poor households) to join the group Posdaya to carry out productive economic activities, (2) establish / activate integrated service post (posyandu) in Posdaya group, (3) establish / activate TPA or early childhood education (PAUD) and strengthen 'Majlis Ta'lim'. In 2013 UNMA has formed 50 Posdaya spread in 13 districts of Pandeglang with as many as 783 students and field supervisor lecturers as many as 50 people.

Community service programs organized by the two universities are according with the principle of tri dharma college described in the Law of the Republic of Indonesia No.12 of 2012 Article 58, paragraph 2, that "The function and role of the College should be implemented through the activities of Tri Dharma, Tri Dharma explain in the Law on National Education System (Education) No.20 of 2003 article 20, paragraph 2 of "Universities are obliged to provide education, research, and community service." This is in accordance with the educational goals that have been described in the regulation No.60 of $1999^{28}$ that "Preparing students to become members of the community, who have academic ability, develop and disseminate knowledge, and seeking its use to improve people's lives and enrich the national culture".

Review from the theory of community development, community service programs that have been carried both of universities done with social intervention community service approach, Glen stating this intervention model in Isbandi $^{29}$ that public service approach has three main concerns, as follow:

1) Develop services and responsive organizations to community needs

2) Maximize the opportunity for the people to involved in the organization activities

3) Support the collaboration among several organizations in order to meet the public interest.

Third attention above has been done by both universities in the implementation of community service through Posdaya programs that involve the community that related with the above three main concern. In addition, UNMA has illiteracy program and development of UKM and both of 
them based on community needs and community involvement. UMT also conduct educational programs to the community and service to the community according to community needs.

\subsection{Impact Analysis of Community Service Program}

$\operatorname{Randy}^{30}$ stated that the empowerment process should include 'enabling' (create a conducive atmosphere), 'empowering' (strengthening the capacity and capability of the public), 'protecting' (protection from injustice), 'supporting' (counseling and support), and 'foresting' (maintain conducive conditions stay balanced). In the process of public service at both the university has adopted the enabling, empowering, protecting, supporting and foresting as KKN-PPM POSDAYA program, this program has contributed to the community and involve the local community.

\subsection{Community Service Impact to Lecturers, Students and the Community in Adding Value to Social Change}

LP3M in performing its duties need to open cooperation network partnership with other relevant institutions that related to programs that proclaimed by LP3M, the local government, nongovernment, public universities / private universities, non-govermental organization and the private sector. Because in fact an attempt to empower the people is the responsibility of all parties. Such cooperation needs to be done in order to formulate and implement a comprehensive community programs and sustainable.

Target community of service activities based on society around campus and off campus or Patronage village who work as partners to face the problems and solve it, as well as an application of the purpose of LP3M UMT, that increase people out of backwardness (religious, economic, health, education, legal, technological, social, political, and cultural) to improve capabilities through the implementation of community service.

All activities at the University Muhamdiyah of Tangerang that oriented to community service are the contribution from component of the academic community. Therefore, all activity under the coordination of LP3M supported by academic units that exist in every faculty. Especially for Islamic Faculty, activities in 2012 until the ongoing was raising land acquisition of boarding school and its budget raised from lecturers for benefaction.

Contributions of Muhammadiyah University in the district Karet of Tangerang guided by LP3M among others: Encourage people in religious education such as recitals in the mosque, fostering madrasah and guiding village target environment ${ }^{26}$.

UNMA as a scientific institution should always be based on pure determination and motivation to serve through scientific methodology, both in the planning, implementation and evaluation. Community service activities conducted by lecturers and students do in the name of universities. Although in practice it can be done by an individual or group of Academicians College.

Contributions of Mathalul Anwar as a college for society, especially on Sodong village, district Saketi of Pandeglang, after the College of Mathla'ul Anwar and its boarding school in Kampung 
Sodong is experiencing rapid change, in addition to changes the village it is also change society's perspective, They felt a huge benefit, once only a few people who go higher education, now a lot of people there who graduated from UNMA and many who studied at Mathla'ul Anwar boarding school. Even the public economy has increased because many villagers who open dormitory or boarding house for students and stalls, many lecturers of UNMA that provides guidance and instruction in mosques in this village. So the benefit of Mathla'ul Anwar to the surrounding community becomes a blessing.

The influence of the internal condition state college dalah of UNMA give comfort to student by giving adequate facilities to support activities of the course that is the cheapness of SPP and wisdom in payment, sometimes it can be repaid or postponed, and some poor students who get help from college. In addition, quality of lecturer, staff, and other effects are very good, so the academic culture in the campus going well and fast.

The development of students increased every year compared to the previous period; this is evidenced by the growing of prospective students who enroll in UNMA each year carrying more than 1,000 prospective students who enroll in UNMA Pandeglang, Banten. Name of Mathla'ul Anwar Pandeglang, Banten now known in all community life of Banten. Achievement of UNMA is able to build student competence. Many students who won in every competition between campuses. In education, the campus also pay attention to the mastery of English and Arabic as well as competence in the areas of interest, also other talents such as sports, arts and culture, journalism, and others.

The role of extra-campus organization quite influential in coloring paradigm of thinking as students of UNMA Banten as Banten community who are already carrying the label of Islam in the curriculum of the campus. Even in democracies campus, extra-campus movement greatly contributed to the enforcement of the student democracy as a forum to forge a student in terms of leadership.

\section{Conclusions}

Based on the results of research, data analysis, and theoretical discussion and field findings, it can be conclude as follows:

First, the background of the establishment of private Islamic universities (UMT and UNMA) constituted by a non-governmental organization that empowers communities concentrated in the fields of education, so that the programs run by the experience of organization for many years and theories were found based on scientific findings. Vision, mission and philosophy of both universities has led to the concentration of people's life quality, so indirectly community empowerment program has been planned based on the concept of strategic management.

Second, quality planning of community service program at UMT done through several steps, these are: 1) analysis, 2) drafting the program plan, 3) socialization, 4) preparation of budget financing, and 5) documentation. The process of planning program that conducted, the mechanism do on the Executive Board meeting involving the chairman of the study program, the department head, dean, heads of sections and officials of Rector. To realize these programs, the 
implementation team was formed for community service activities that programmed each year, and these programs are individual, some are institutional.

Third, in designing the programs of community service activities at UNMA begun with the analysis of the situation of society. The analysis phase is the beginning of a very important thing which should not be skipped, because the community service activities should be initiated from the intention to help the community. The analysis phase of social situation can be done in two sub-phases, which are divided into several possibilities. The first stage, determine the target audience, whether the wider community as a whole, a particular community, a particular audience or certain organization, or certain people in society; The second stage, determine the problem areas to be analyzed, whether comprehensively, it means trying to find, see and learn overall of problems faced by the target audience.

Fourth, the implementation of community service activities in the UMT must follow procedures which have been assigned. Overall LP3M determine the procedure as follows: On the initiative of the faculty or department making plan about activities or academic staff (lecturers) to apply to the rector, approved or not it will be replied, and if it accepted it will immediately issue a letter of assignment; If necessary involving the team, such as students, then the responsibility activities in the control of lecturer; academic staff involved as an escort, if needed. During the implementation of the community service activities carried out, monitoring and evaluation carried out by the monitoring team to provide advice and feedback to the implementers of community service; and after the activity is completed, both implementing community service and the monitoring team have to submit an implementation report to the LP3M.

Fifth, the evaluation of community service at UMT conducted from early planning to implementation by a team of internal auditors with the standard guidelines for community service, and results are reported in writing. Report of activities submitted to several institutions concerned, in accordance with the duties. Policy of community service program at the University of Muhammadiyah especially UMT done in the format of empowerment and community service practicum.

\section{Acknowledgements}

The Author would like to Acknowledgment for contribution of leader and lecturer in Muhammadiyah University of Tangerang (UMT) and the Mathla'ul Anwar University (UNMA) Pandeglang, Banten Province, Indonesia. Besides that, The Author would like to Acknowledgment for all student's Department Islamic Religion Education at State Islamic Institute of Sultan Maulana Hasanuddin Banten as partnership study in teaching and learning programe.

\section{Endnotes}

[1] Dedi Mulyasana, Pendidikan Bermutu dan Berdaya Saing, (Bandung:PT Remaja Rosdakarya, 2011), Page 13.

[2] Law No. 20 of 2003 about National Education System

[3] Dirjen Diktis, 2009, halaman 112. 
[4] Renstra Pendis, 2010-2014

[5] Syahrijal Abas, 2009, page 176.

[6] Lexy Moleong, Qualitative Research Methodology, (Bandung: PT Youth Rosdakarya, 2001), page 247.

[7] Interview Result with the Chairman of the LPM, 26 February, 2013.

[8] Interview Result with Chairman of the Institute of Quality Assurance of UNMA Pandeglang

[9] Interview Result with the Chairman of the Quality Assurance organization of UMT Tangerang

[10] Interview Result with the Assistant Dean of UNMA Pandeglang.

[11] Interview Result with employees and lecturer of UMT Tangerang

[12] Doc. A

[13] Interview Result with Chairman of the Institute of Quality Assurance of UMT Tangerang

[14] Interview Result with Employees and Lecturers of UNMA Pandeglang

[15] Doc.E.1.

[16] Interview Result with employees and Lecturer Lecturer of UMT Tangerang

[17] Doc.E.2.2013

[18] Interview Result with the Head of Department of UNMA Pandeglang

[19] Doc.E.2.2013

[20] Interview Result with the Head of Department of UMT Tangerang.

[21] Interview Result with Vice Rector of UMT Tangerang

[22] Interview Result with Quality Assurance Organization of UMT Tangerang

[23] Interview Result with the Institute of Quality Assurance of UNMA Pandeglang

[24] Interview Result with Employees and Lecturers of UNMA

[25] George R. Terry, Principles of Management, (Illinois: Richard D. Irwin, 1968).

[26] Nana Mintarti, Technical Planning Program for Community Empowerment, (Jakarta: IMZ Publishers, 2012).

[27] Suharto, Development, Social Policy and Social Work, (Bandung: Institute for Development Studies, 1997).

[28] PP No. 60 of 1999 on Higher Education

[29] Isbandi, Empowerment, Community Development and Community Intervention, (Jakarta: Faculty of Economics Publisher of University of Indonesia, 2003).

[30] Randy, Empowerment Management, An Introduction and guidance for community empowerment, (Jakarta: Elex Media Komputindo, 2007).

\section{References}

[1] Adi, Isbandi Rukminto. (2003). Pemberdayaan, Pengembangan Masyarakat dan Intervensi Komunitas. Pengantar pada Pemikiran dan Pendekatan Praktis. Jakarta: Lembaga Penerbit Fakultas Ekonomi Universitas Indonesia.

[2] Allen, Jean Alexander, (2004). Strategi Membangun Tim Tangguh, Terjemahan Ina Kurniawati, Jakarta: Prestasi Pustaka Publisher.

[3] Álvarez, Amber Wigmore-. Lozano, Mercedes Ruiz-. (2012).University Social Responsibility (USR) in the Global Context: An Overview of Literatur. Spain: Business \& Professional Ethics Journal, 31:3-4.

[4] Bush, Tony \& Coleman, Mariame, (2006). Leadership and Management in Education, Terjemahan Fahrurrozi. Yogyakarta: IRCiSoD. 
[5] Cooper, Robert K. dan Sawaf, Ayman. (1998). Executive SQ: Kecerdasan Emosional dalam Kepemimpinan dan Organisasi. Jakarta: PT Gramedia Pustaka Utama.

[6] Eko Indrajit, R dan Djokopranoto, R. (2006). Manajemen Perguruan Tinggi. Yogyakarta: Penerbit Andi.

[7] Ghafur, Hanief Sah. (2008). Manajemen Penjaminan Mutu Perguruan Tinggi di Indonesia. Jakarta: Bumi Aksara.

[8] Harsono. (2008). Model-Model Pengelolaan Perguruan Tinggi : Prespektif Sosiopolitik. Jogjakarta : Pustaka Pelajar.

[9] Indrajit, R.Ekon \& Djokopranoto, R., (2006). Manajemen Perguruan Tinggi Modern. Yogyakarta: Penerbit Andi.

[10] Lewis, Ralph G. and Smith, Douglas H. (1994). TotalQuality Management in Higher Education. Delray Beach, Florida: St. Lucie Press.

[11] Mile, Mathew B.,A Michael Huberman. (1992) Analisis Data Kualitatif. Penerjemah Tjetjep Rohendi Rohidi. Jakarta: Universitas Indonesia.

[12] Mintarti, Nana. (2012). Teknis Perencanaan Program Pemberdayaan Masyarakat. (Workshop Pemberdayaan Masyarakat). Jakarta : IMZ

[13] Moleong, Lexy J. (2001). Metodologi Penelitian Kualitatif. Cetakan ke 14. Bandung: PT Rosdakarya,

[14] Mulyasana, Dedi. (2011). Pendidikan Bermutu dan Berdaya Saing. Bandung: Remaja Rosdakarya.

[15] Panduan Pelaksanaan Penelitian dan Pengabdian Pada Masyarakat Edisi VI (2002). Direktorat Pembinaan Penelitian dan Pengabdian Pada Masyarakat, Direktorat Jenderal Pendidikan Tinggi.

[16] Pedoman Penjaminan Mutu (Quality Assurance) Pendidikan Tinggi. (2003). Direktorat Jenderal Pendidikan Tinggi.

[17] Praktek Baik Dalam Penjaminan Mutu Perguruan Tinggi. (2005). Direktorat Pembinaan Akademik dan Kemahasiswaan, Direktorat Jendral Pendidikan Tinggi Departement Pendidikan Nasional.

[18] Rahman Ali Nur. (2005). Makalah: Paradigma dan Orientasi Pengabdian pada Masyarakat di Perguruan Tinggi Agama Islam. UIN Malang. Tidak dipublikasikan.

[19] Rivai, Veithzal. Murni, Sylviani. (2009). Education Management. Jakarta: Rajawali Press.

[20] Sailah, Illah (2003). "Organisasi Perguruan Tinggi Yang Sehat", Makalah pada Seminar Nasional dan Lokakarya Manajemen Pengelolaan Perguruan Tinggi, Dikti, Garden Palace Hotel, Surabaya.

[21] Salim, Agus. (2001) Teori dan Paradigma Penelitian Sosial (dari Denzin Guba dan Penerapannya). Cetakan Pertama. Yogyakarta: PT Tiara Wacana.

[22] Sallis, Edward, (2008). Total Quality Management in Education. Jogjakarta: IRCiSoD.

[23] Sallis, Edwar. (2011). Manajemen Mutu Terpadu Pendidikan.Yogyakrta: IRCiSoD.

[24] Sanusi, Ahmad. (2009). Kepemimpinan Sekarang dan Masa Depan. Bandung: Prospeat.

[25] Slamet, Margono. (2004). Merekayasa Jalan Menuju Transformasi Perguruan Tinggi. Jakarta: Forum Heds - BKS PTN Barat.

[26] Straub, Joseph T. (2006), Membangun \& Memimpin Tim, Terjemahan At's Line, Yogyakarta: Tugu Publisher.

[27] Sudjana. (2010). Manajemen Program Pendidikan Untuk Pendidikan Non Formal dan pengembangan sumber daya manusia. Bandung: Fallah Production.

[28] Suharto, Edi (1997), Pembangunan, Kebijakan Sosial dan Pekrjaan Sosial: Spektrum Pemikiran, Bandung: Lembaga Studi Pembangunan.

[29] Sumarjoko, Bambang. (2010). Membangun Budaya Pendidikan Mutu Perguruan Tinggi. Surakarta: Pustaka Pelajar.

[30] Sumodiningrat, Gunawan. (1999). Pemberdayaan Masyarakat dan Jaring Pengaman Sosial. Jakarta: PT. Gramedia Pustaka Utama.

[31] Tampubolon. (2001). Perguruan Tinggi Bermutu Paradigma Baru Manajemen Pendidikan Tinggi Menghadapi Tantangan Abad ke-21. Jakarta: Gramedia Pustaka Utama. 
[32] Terry, George R. (1968). Principles of management. Illinois : Ricard D. Irwin

[33] Thoyib, Muhammad. (2010). Manajemen Mutu Program Pendidikan Tinggi Islam dalam Konteks Otonomi Perguruan Tinggi. Bandung: Pascasarjana Universitas Islam Nusantara.

[34] Undang-Undang Republik Indonesia Nomor 20 Tahun 2003 Tentang Sistern Pendidikan Nasional.

[35] Undang-Undang Republik Indonesia Nomor 14 Tahun 2005 Tentang Guru dan Dosen.

[36] Usman, Husaini, (2006). Manajemen: Teori, Praktik dan Riset Pendidikan. Jakarta: PT Bumi Aksara.

[37] Widyatomo, Bambang. (2010). Manajemen Perguruan Tinggi Agama Islam Swasta Unggukan di Provinsi DKI Jakarta. Bandung: Pascasarjana Univeersitas Islam Nusantara.

[38] Wijatno. (2009). Pengelolaan Perguruan Tinggi secara Efisien, Efektif, dan Ekonomis. Jakarta: Penerbit Salemba Empat.

[39] Wrihatnolo, R, Randy dan Riant Nugroho. 2007. Manajemen Pemberdayaan, Sebuah Pengantar dan panduan untuk pemberdayaan Masyarakat. Jakarta: Elex Media Komputindo.

*Corresponding author.

E-mail address: agusgunawan6129@yahoo.com 